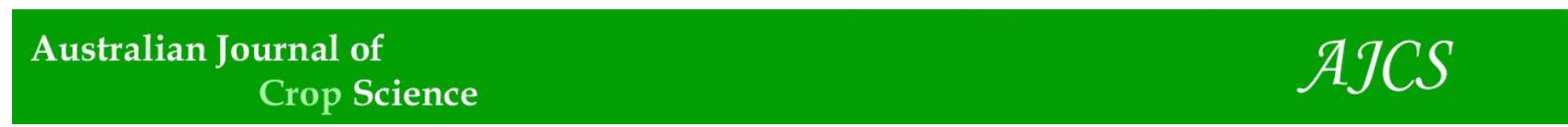

AJCS 15(12):1466-1470 (2021)

ISSN:1835-2707

doi: 10.21475/ajcs.21.15.12.p3339

\title{
Susceptibility of Urochloa species subjected to pre-emergence application of [imazapyr + imazapic] herbicide
}

\author{
Fenelon Lourenço de Sousa Santos*1, Adriano Stephan Nascente², Mabio Chrisley Lacerda², Francine \\ Neves Calil', Fernando Couto de Araújo'
}

\author{
'Department of Agronomy, Universidade Federal of Goiás, UFG, Brazil \\ ${ }^{2}$ National Research Center for Rice and Beans - Embrapa Arroz e Feijão, Brazil
}

\begin{abstract}
Intercropping imidazolinone resistance crops, resistant to herbicides imazapyr + imazapic, with forage species may be a viable alternative to recover degraded pasture areas. This practice requires herbicides to slow down development of the forage and avoid reduced rice yield. However, as it is a relatively new technology, the proper management of this herbicide to control forage is not known. The objective of this study was to determine the susceptibility of forages Urochloa ruziziensis, U. brizantha cv. Paiaguás, and $U$. brizantha cv. Marandu, submitted to the pre-emergence application of the herbicides [imazapyr + imazapic]. The experimental design was completely randomized in a $3 \times 5+3$ factorial scheme with five replications. Treatments consisted of the combination of the three species (Urochloa ruziziensis, U. brizantha cv. Paiaguás, and U. brizantha cv. Marandu) and five intervals between herbicide application in the soil and forage sowing $(0 ; 5 ; 10 ; 15$; and 20 days after its application), in addition to three control treatments, without herbicide application. This study found that application of herbicide on the day of forage sowing for intercropping with imidazolinone resistance crops is not feasible. Increasing the time interval between herbicide application and forage sowing provides increased development of $U$. brizantha cvs. Marandu and Paiaguás. The species $U$. ruziziensis is more susceptible to pre-emergence application imazapyr + imazapic. According to the results, U. brizantha cvs. Marandu and Paiaguás are more suitable to be managed by imidazolinone herbicides to recover degraded pasture areas.
\end{abstract}

Keywords: Clearfield; degraded pasture; imidazolinones; Kifix; livestock crop integration.

\section{Introduction}

Brazil has an area of approximately 100 million hectares of highly degraded pastures (Dias-Filho, 2016), with lower capacity of meat or milk production per unit of land occupied. In this context, integrated crop-livestock, a mixed system of crop and livestock farming, is a viable alternative to recover these areas (Costa et al., 2016; Santos et al., 2020).

With an integrated crop-livestock, grain production can be used to recover these degraded pastures, reducing the planting cost and increasing food production in a sustainable way without opening new areas, since recovered pastures provide higher zootechnical indexes (Borghi et al., 2013). In Brazil, the use of intercropping between crops such as corn (Mateus et al., 2019), sorghum (Santos et al., 2020; Da Silva et al., 2020), soybeans (Erasmo et al., 2017; Rodrigues et al., 2018) and sunflower (Cruvinel et al., 2017; Dos Santos et al., 2019) are increasing, mainly with forages of the genus Urochloa (Da Silva et al., 2018). In many cases, the grain crops cover the costs of pasture renewal.

The advent of the Clearfield ${ }^{\circ}(\mathrm{CL})$ system including cultivars with a broad-spectrum herbicide resistance gene, usch as in corn, rice and sunflower crops (Nakka et al., 2019), has increased the possibilities of forage control that can avoid competition with crops, but can affect the development of fodder in integrated production systems. Thus, using herbicide can reduce grass development and allow full development of crop cultivation to recover pastures in degraded soils, as already demonstrated in conventional corn cultivation (Ceccon et al., 2010; Adegas et al., 2011). After harvest, the forage, already established, can fully develop and form the pasture.

In the CL system, the herbicide of the chemical group imidazolinone called Kifix (imazapyr + imazapic), which is systemic and selective for CL cultivars, can be applied before or after emergence of crops without harming it (Rangel et al., 2010; Marchesan et al., 2011). The high persistence in the soil of herbicides belonging to the imidazolinone group is a noted feature of these products (Loux and Reese, 1993), in which case the residual effect of the herbicide in the soil may increase weed control. However, in an intercropping situation, it may compromise the development of the other species, as in the case of foliage, which is susceptible to the molecules.

As it is a relatively new technology, few studies have examined the pre-emergence application of herbicide [imazapyr + imazapic] for intercropping with $\mathrm{CL}$ crops for pasture renewal. Thus, for imidazolinone resistance crops (IMI) in polyculture, the appropriate time to apply the herbicide in pre-emergence to delay the growth of the forage without eliminating it is still unknown. Information on specific behavior of Urochloa species with potential for intercropping with $\mathrm{CL}$ crops, when submitted to the herbicide [imazapyr + imazapic] applied in pre-emergence is scarce. 
Assays in controlled conditions (greenhouse) reveal the effect of herbicide application without the influence of weeds. In field conditions, weeds could lead to development of crops and weeds only, without forage, which are the targets of the present study. Thus, the objective of this work was to determine the susceptibility of forages Urochloa ruziziensis, U. brizantha cv. Paiaguás, and U. brizantha cv. Marandu, submitted to the application of the herbicide imazapyr + imazapic in pre-emergence.

\section{Results and Discussion}

\section{Urochloa emergence}

The results found significant interaction between the evaluated species and the interval between herbicide application and forage sowing for all variables analyzed. Similarly, herbicide application interfered with all variables compared to the control treatment.

At 5 days after sowing (DAS), only the treatments where forages were sown 20 days after herbicide application did not have reduced emergence plant, compared to control (Table 1). However, at the 10 and 30 DAS evaluations, all treatments were affected by herbicide application, with a reduced number of emerged plants compared to control. Therefore, the application of the herbicide imazapyr + imazapic significantly reduced the number of forage plants 10 days after sowing. This is due to the residual effect of the herbicide and its systemic way of acting on the plant which can germinate but may die with prolonged exposure to the herbicide.

At all evaluation periods, interval between herbicide application and forage sowing increased the number of emerged plants of all the $U$. brizantha cultivars (Figure 1). This behavior is probably because the longer time interval between herbicide application and sowing reduced the availability of herbicide molecules in the surface layer, as the constant herbicides in the mixture have high solubility (Tu et al., 2016). Studies conducted with cover crops submitted to the herbicide imazapyr also found the highest plant survival with longer intervals between herbicide application and sowing species (Zaccaro et al., 2017).

Among the evaluated species, Urochloa ruziziensis was most susceptible to the herbicide used. In this species, all plants died in the period between the second (10 DAS) and the third evaluations (30 DAS) (Table 1). The plants were susceptible to molecules with this mechanism of action. Thus, after herbicide application, their growth was ceased between 7 and 10 days (Oliveira Jr. et al., 2011), justifying the reduction in the amount of plants observed between the second (Figure 1B) and the third evaluation (Figure 1C). This behavior is possibly due to the mechanism of action of the herbicide, which inhibits the synthesis of Acetolactate Synthase (ALS), an essential enzyme for the synthesis of valine, lysine, and isoleucine branched chain amino acids (Rangel et al., 2010).

Studies on Urochloa brizantha, U. decumbens, and U. ruziziensis species found different susceptibility of Urochloa species to glyphosate herbicide. The authors report that Urochloa ruziziensis was the most susceptible to the herbicide (Brigenthi et al., 2011). This may indicate that this species is more susceptible to herbicide action, regardless of the mechanism of action, because the herbicides glyphosate and imazapyr + imazapic, U. ruziziensis presented possible differential susceptibility in relation to other species.
In the present experiment, the plants that received herbicide application had interveinal chlorosis and apical shoots. The same symptoms were reported in other grasses such as pearl millet (Dan et al., 2011) and sugarcane (Obara et al., 2015).

Between the second and third evaluation (30 DAS), the species $U$. brizantha cV. Paiaguás and $U$. brizantha cv. Marandu reduced their plant stand (Figures $1 \mathrm{~B}$ and $1 \mathrm{C}$ ). However, survival tended to proportionally increase with increasing interval between herbicide application and forage sowing (Figure $1 \mathrm{C}$ ), indicating that $U$. brizantha cultivars have greater tolerance to the evaluated herbicides than $U$. ruziziensis. Herbicide selectivity is more related to the genetic characteristics of the evaluated species than to the chemical characteristics or dose of the applied product (Souza et al., 2009).

Regardless of the species used, when the sowing was performed on the same day of the herbicide application, the seeds germinated but all emerged plants died before the last evaluation at 30 DAS (Table 1). Therefore, we concluded that, this practice does not work for this polyculture. However, in subsequent plantings, the herbicide did not totally inhibit the development of $U$. brizantha cultivars, as long as a minimum grace period of 5 and 10 days was permitted for sowing $U$. brizantha cv. Paiaguás and $U$. brizantha cv. Marandu, respectively. The longer the period was between herbicide application and forage sowing, the greater the number of emerged plants at 30 DAE (Figure 1C).

\section{Biomass accumulation}

For biomass production, the increase in the time interval between herbicide application and forage sowing promoted plant development, both in the shoots (Figure 2A) and roots (Figure 2B). Hence, the time interval between herbicide application and forage sowing is very important to avoid its reduced development and even death, which would make pasture formation unfeasible. The increased shoot and root biomass in Urochloa species are proportional due to the root anatomy of the species, which gives them a high root density per plant (Santos et al., 2015).

The minimum interval between application and sowing that allowed plant survival was 5 days for $U$. brizantha cV. Paiaguás and 10 days for $U$. brizantha cv. Marandu. In subsequent plantings, plant development was occurred proportionally to the interval between application days and sowing, both for shoot biomass production (Figure 2A) and root biomass accumulation (Figure $2 \mathrm{~B}$ ). This reinforces the information that this herbicide acts on these forages when used in pre-emergence, affecting the formation and establishment of pasture.

During period between herbicide application and forage sowing, the herbicide probably degraded, which reduced its deleterious effect on plants. This behavior was also observed in pearl millet (Dan et al., 2011) in an assay evaluating the activity of the herbicide imazethapyr $\left(0.10 \mathrm{~kg} \mathrm{ha}^{-1}\right)$ on the crop, where the authors report that sowing less than 40 days after application causes reduction in the plant stand due to the herbicide bioactivity in the soil.

In the present work, the dose used was higher than the dosage recommended on the package, precisely to have a safety margin and verify the effect of herbicide on forage development. Under field conditions the behavior of herbicides on these species may produce different results. 
Table 1. Emerged plants of different Urochloa species submitted to the application of the herbicide imazapyr + imazapic in presowing. Santo Antônio de Goiás, GO, 2020.

\begin{tabular}{|c|c|c|c|}
\hline \multirow{2}{*}{$\begin{array}{l}\text { Sowing time related to } \\
\text { herbicide application }\end{array}$} & \multicolumn{3}{|c|}{ Number of emerged plants per vase } \\
\hline & Urochloa ruziziensis & Urochloa brizantha cv. Paiaguás & Urochloa brizantha cv. Marandu \\
\hline & 5 DAS & & \\
\hline 0 & $3.65^{*}$ & $1.02^{*}$ & $0.71^{*}$ \\
\hline 5 & $4.01 *$ & $1.41^{*}$ & $0.71^{*}$ \\
\hline 10 & $3.91 *$ & $2.74 *$ & $2.12^{*}$ \\
\hline 15 & $3.82 *$ & $2.55^{*}$ & $2.12^{*}$ \\
\hline 20 & 5.30 & 4.06 & 4.03 \\
\hline \multirow[t]{2}{*}{ Control } & 5.77 & 4.16 & 4.01 \\
\hline & & 10 DAS & \\
\hline 0 & $4.34 *$ & $3.07^{*}$ & $1.37^{*}$ \\
\hline 5 & $4.43^{*}$ & $3.50 *$ & $2.07^{*}$ \\
\hline 10 & $4.32 *$ & $4.32 *$ & $2.97^{*}$ \\
\hline 15 & $3.96^{*}$ & $3.94 *$ & $3.07 *$ \\
\hline 20 & $5.26 *$ & $3.80 *$ & $4.32 *$ \\
\hline \multirow[t]{2}{*}{ Control } & 6.24 & 5.49 & 5.97 \\
\hline & & 30 DAS & \\
\hline 0 & $0.71^{*}$ & $0.71^{*}$ & $0.71^{*}$ \\
\hline 5 & $0.71^{*}$ & $1.12^{*}$ & $0.71^{*}$ \\
\hline 10 & $0.71^{*}$ & $0.91^{*}$ & $0.94^{*}$ \\
\hline 15 & $0.71^{*}$ & $1.02 *$ & $1.27^{*}$ \\
\hline 20 & $0.71 *$ & $1.22 *$ & $1.63^{*}$ \\
\hline Control & 5.17 & 4.59 & 5.59 \\
\hline
\end{tabular}

DAS = Days after sowing; ${ }^{*}=$ differs from control portion by Dunnett's test $(p<0.05)$.
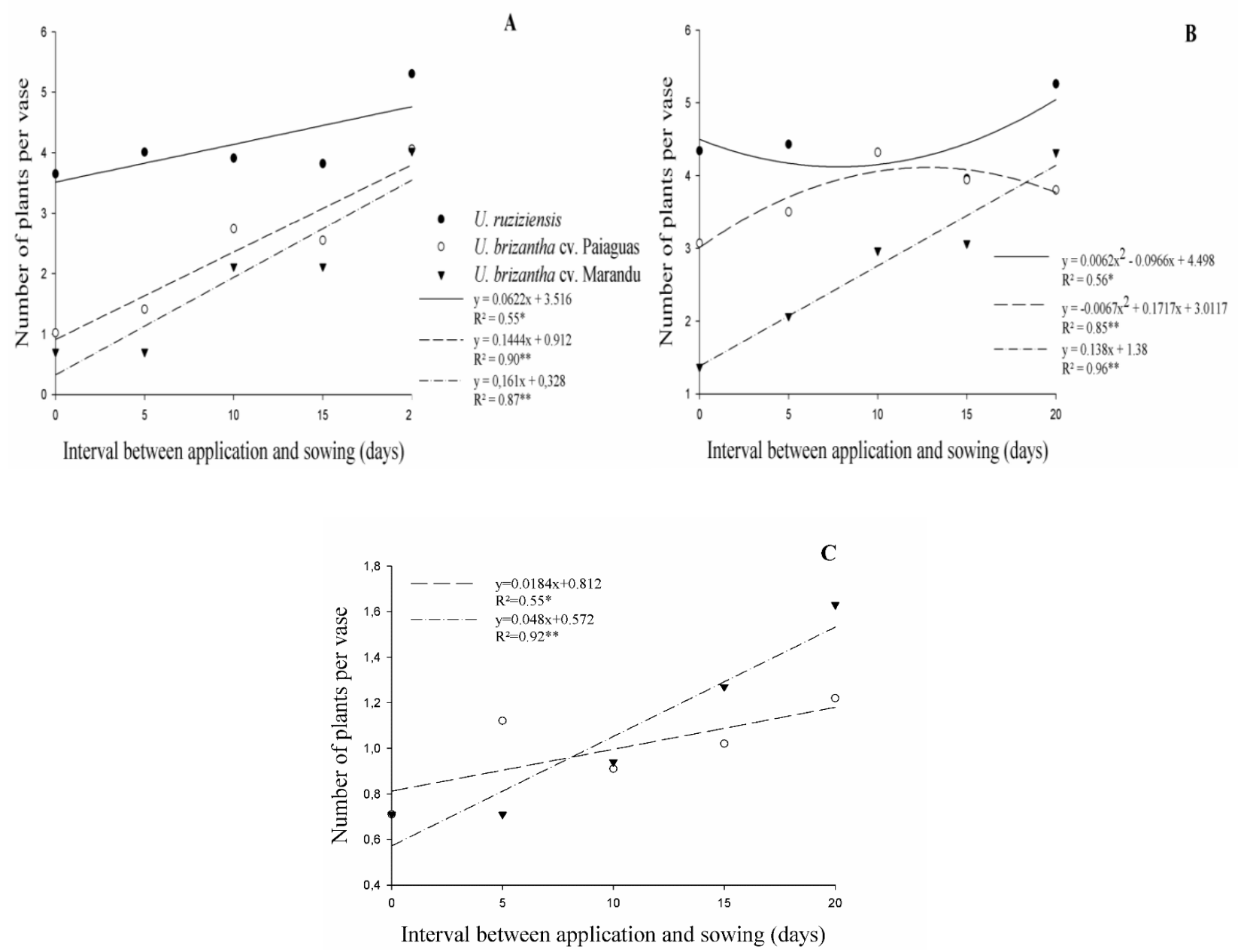

Figure 1. Emergence of Urochloa species subjected to application of the herbicide imazapyr + imazapic at 5 (A), 10 (B), and 30 (C) days after sowing as a function of interval between application and sowing time. Santo Antônio de Goiás, GO, 2020. 

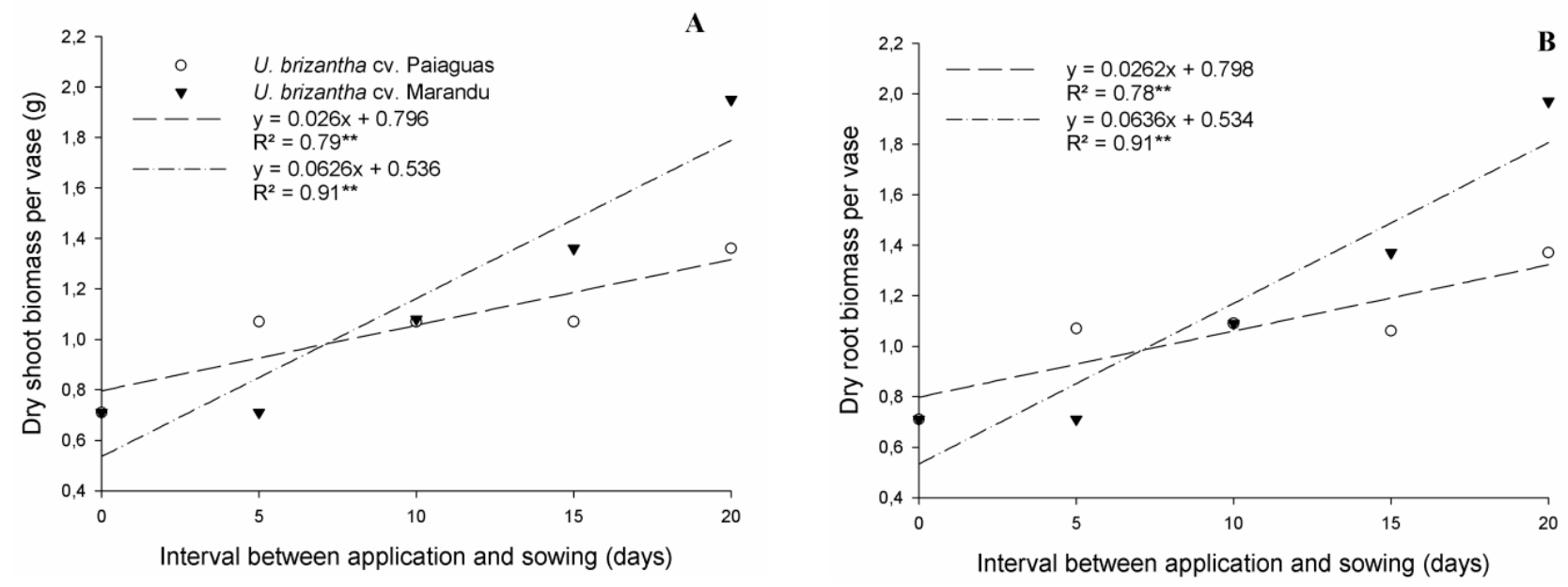

Figure 2. Biomass of dry shoot (A) and root (B) in Urochloa species at 30 days after emergence as a function of interval between application and sowing time submitted to the pre-emergent application of the herbicide imazapyr + imazapic. Santo Antônio de Goiás, GO, 2020.

Nevertheless, based on the work developed here, caution should be taken in the management of forages when aiming to intercrop $\mathrm{CL}$ crops with these grasses, since the inadequate application of herbicide may make this technology unfeasible.

\section{Materials and Methods}

\section{Experimental site}

The experiment was conducted in a greenhouse, between August and October 2017, in Santo Antônio de Goiás, GO, Brazil. Soil was used from the arable layer $(0.00-0.20 \mathrm{~m})$ of a Latossolo Vermelho acriférrico típico (eq. Oxisol) (Santos et al., 2018), with clay texture with the following physicochemical characteristics: $\mathrm{pH}$ in $\mathrm{H}_{2} \mathrm{O}$ : 5.2 ; $\mathrm{Ca}$ : 9.0 $\mathrm{mmol}_{\mathrm{c}} \mathrm{dm}^{-3} ; \mathrm{Mg}: 2.6 \mathrm{mmol}_{\mathrm{c}} \mathrm{dm}^{-3} ; \mathrm{Al}: 1.0 \mathrm{mmol}_{\mathrm{c}} \mathrm{dm}^{-3} ; \mathrm{H}+\mathrm{Al}$ : $24 \mathrm{mmol}_{\mathrm{c}} \mathrm{dm}^{-3}$; P: $0.9 \mathrm{mg} \mathrm{dm}^{-3} ; \mathrm{K}: 64.0 \mathrm{mg} \mathrm{dm}^{-3} ; \mathrm{Cu}: 4.6 \mathrm{mg}$ $\mathrm{dm}^{-3}$; Zn: $2.0 \mathrm{mg} \mathrm{dm}^{-3}$; Fe: $48.0 \mathrm{mg} \mathrm{dm}^{-3}$; $\mathrm{Mn}: 37.6 \mathrm{mg} \mathrm{dm}^{-3}$; OM: $19.93 \mathrm{~g} \mathrm{~kg}^{-1}$; Clay: $417 \mathrm{~g} \mathrm{~kg}^{-1}$; Silt: $155 \mathrm{~g} \mathrm{~kg}^{-1}$; Sand: $428 \mathrm{~g}$ $\mathrm{kg}^{-1}$.

\section{Experimental design and treatments}

The experimental design was completely randomized in a $3 \times 5+3$ factorial scheme with five replications. The treatments consisted of the combination of three forage species (Urochloa ruziziensis, U. brizantha cv. Paiaguás, and $U$. brizantha cv. Marandu) and five different intervals between the application of the herbicide Kifix $\left(525 \mathrm{~g} \mathrm{~kg}^{-1}\right.$ imazapyr $+175 \mathrm{~g} \mathrm{~kg}^{-1}$ imazapic) and forage sowing $(0,5,10$, 15 , and 20 days after herbicide application). Additionally, the controls treatments were the three forages sown without herbicide application.

\section{Plant material}

One week before sowing forage, $2 \mathrm{~kg}$ pots were completely filled with soil and fertilized with the formulated N- $\mathrm{P}_{2} \mathrm{O}_{5}-\mathrm{K}_{2} \mathrm{O}$ (05-30-15), at a dosage equivalent to $200 \mathrm{~kg} \mathrm{ha}^{-1}$. The herbicide was applied at a dosage equivalent to $150 \mathrm{~g}$ p.c. $\mathrm{ha}^{-1}$, at pre-emergence stage, using a $30 \mathrm{psi}^{\mathrm{CO}_{2}}$ pressurized costal spray with 8002 nozzles and $200 \mathrm{~L} \mathrm{ha}^{-1}$ spray volume.
For forage sowing, 40 viable pure seeds per vase were incorporated at a depth of two centimeters. The pots were irrigated daily to keep moisture close to field capacity.

\section{Traits measured}

After herbicide application, the number of plants that emerged in each vase was evaluated at 5, 10, and 30 days after forage sowing (DAS). At the last evaluation (30 DAS), the plants were cut close to the ground from each vase, and the roots were washed. The plant material was taken to drying in an oven at $65{ }^{\circ} \mathrm{C}$ for $72 \mathrm{~h}$ to determine the dry biomass of the shoot and root.

\section{Statistical analysis}

The data obtained were submitted to analysis of variance by the $F$ test $(p \leq 0.05)$. Dunnett's test $(p \leq 0.05)$ was performed to compare treatment without application (control) with those that received herbicide application. The analysis of the plant emergence and biomass accumulation variables was performed with the data transformed into $\sqrt{(x+0.5)}$. To determine the effect of the interval between herbicide application and forage sowing development of the forage, regression analysis was performed. All statistical analyzes were done using the $\mathrm{R}$ statistical software.

\section{Conclusions}

This study found that using the formulated mixture of the herbicides imazapyr + imazapic on the day sowing is unfeasible for $\mathrm{CL}$ crops intercropping with forages $\mathrm{U}$. ruziziensis and U. brizantha cvs. Marandu and Paiaguás. The increase in the interval between the application of the commercial mixture of the herbicides imazapyr + imazapic and the forage sowing allowed increased development of $U$. brizantha cv. Marandu and Paiaguás. U. ruziziensis species is more susceptible to pre-emergence herbicides imazapyr + imazapic and possibly not suitable for use in $\mathrm{CL}$ intercropping. 


\section{Acknowledgements}

The authors thanks the Conselho Nacional de Desenvolvimento Científico e Tecnológico (CNPq) and Funcação de Amparo a Pesquisa do Estado de Goiás (FAPEG) for their financial support and granting the scholarship.

The authors declare that have no conflicts of interest.

\section{References}

Adegas FS, Voll E, Gazziero DLP (2011) Manejo de plantas daninhas em milho safrinha em cultivo solteiro ou consorciado à braquiária ruziziensis. Pesqui Agropecu Bras. 46:1226-1233.

Borghi E, Crusciol CAC, Nascente AS, Sousa VV, Martins GP, Costa C (2013) Sorghum grain yield, forage biomass production and revenue as affected by intercropping time. Eur J Agron. 51:130-139.

Brighenti AM, Sobrinho FS, Rocha WSD, Martins CE, Demartini D, Costa TR (2011) Suscetibilidade diferencial de espécies de braquiária ao herbicida glifosato. Pesqui Agropecu Bras. 46(10):1241-1246.

Ceccon G, Matoso AO, Neto Neto AL, Palombo L (2010) Uso de herbicidas no consórcio de milho safrinha com Brachiaria ruziziensis. Planta Daninha. 28(2):359-364.

Costa RRGF, Costa KAP, Santos CB, Severiano EC, Epifanio OS, Silva JT, Teixeira DAA, Da Silva VR (2016) Production and nutritional characteristics of pearl millet and Paiaguas palisadegrass under different forage systems and sowing periods in the offseason. Afr J Agr Res. 11(19):1712-1723.

Cruvinel WS, Costa KAP, Da Silva AG, Severiano EC, Ribeiro MG (2017) Intercropping of sunflower with Brachiaria brizantha cultivars during two sowing seasons in the interim harvest. Semin-Cienc Agrar. 38(5):3173-3192.

Da Silva A, Santos FLS, Barretto VCM, Freitas RJ, Kluthcouski J (2018) Recuperação de pastagem degradada pelo consorcio de milho, Urochloa brizantha cv. Marandu e guandu. Revista de Agricultura Neotropical. 5(2):39-47.

Da Silva JT, Costa KAP, Silva VC, Souza WF, Teixeira DAA, Severiano EC (2020) Morphogenesis, structure, and dynamics of Paiaguas palisadegrass tillering after intercroping with sorghum for the recovery of pasture in different forage systems. Biosci J. 36(5):1663-1675.

Dos Santos JMS, Peixoto CP, Da Silva MR, Almeida AT, De Castro AMPB (2019) Agronomic and productive characteristics of sunflower intercropped with forage in a crop-livestock integration system. Caatinga. 32(2):514-525.

Dan HA, Barroso ALL, Dan LGM, Procópio SO, Oliveira JR RS, Simon GA, Munhoz DM (2011) Atividade residual de herbicidas aplicados em pós-emergência na cultura da soja sobre o milheto cultivado em sucessão. Planta Daninha. 29(3):663-671.

Dias-Filho MB (2016) Uso de pastagens para produção de bovinos de corte no Brasil: Passado, Presente e Futuro. Embrapa Amazônia Ocidental. 42p.

Erasmo EAL, Gonçalves RC, Da Mata JF, Oliveira VA, Benício LPF (2017) Growth of Brachiaria brizantha planted at different densities and seasons in Santa Fé system with a culture of soybean. Emir J Food Agr. 29(9):658-663.
Loux MM, Reese K (1993) Effect of soil type and $\mathrm{pH}$ on persistence and carryover of imidazolinones herbicides. Weed Technol. 7(2):452-458.

Marchesan E, Massoni PFS, Grohs M, Villa SCC, Avila LA, Roso R (2011) Arroz tolerante a imidazolinonas: banco de sementes de arroz-vermelho e fluxo gênico. Planta Daninha. 29:1099-1105.

Mateus GP, Crusciol CAC, Pariz CM, Costa NR, Borghi E, Costa C, Martello JM, Castilhos AM, Franzluebbers AJ, Cantarella H (2019) Corn intercropped with tropical perennial grasses as affected by sidedress nitrogen application rates. Nutr Cycl Agroecosys. 116:223-244.

Nakka S, Jugulam M, Petterson D, Asif M (2019) Herbicide resistance: Development of wheat production systems and current status of resistant weeds in wheat cropping systems. The Crop J. 7:750-760.

Obara FEB, Brunharo CACG, Melo MSC, Nicolai M, Christoffoleti PJ (2015) Seletividade da associação dos herbicidas imazapic e imazapyr aplicada em diferentes estádios de desenvolvimento da cana-de-açúcar. Nucleus. 12(1):15-26.

Oliveira Júnior RS, Constantin J, Inoue MH (2011) Biologia e manejo de plantas daninhas. Omnipax, 348p.

Rangel PHN, Moura Neto FP, Fagundes PRR, Magalhães Junior AR, Morais OP, Schmidt AB, Mendonça JA, Santiago CM, Rangel PN, Cutrim VA, Ferreira ME (2010) Development of herbicide-tolerant irrigated rice cultivars. Pesqui Agropecu Bras. 45:701-708.

Rodrigues GS, Medeiros RD, Albuquerque JAA, Smiderle OJ, Alves JMA, Da Silva AA (2018) Manejo químico de Urochloa ruziziensis consorciado com soja na savana de

Roraima. Revista Brasileira de Herbicidas. 17(2):581-592.

Santos CB, Costa KAP, Souza WF, Silva AG, Silva VC, Oliveira IP, Brandstette EV (2020) Intercropping of sorghum with Paiaguas palisadegrass in a crop-livestock integration system for pasture recovery. Aust J Crop Sci. 14(7):10721080.

Santos FLS, Melo WRF, Coelho PHM, Benett CRS, Dotto MC (2015) Crescimento inicial de espécies de Urochloa em função da profundidade de semeadura. Revista de Agricultura Neotropical. 2(4):1-6.

Santos HG, Lumbreras JF, Coelho MR, Araujo Filho JC, Cunha TJF (2018) Sistema brasileiro de classificação de solos. 5a ed. Centro Nacional de Pesquisa de Solos. 356p.

Souza JR, Perecin D, Azania CAM, Schiavetto AR, Pizzo IV, Candido LS (2009) Tolerância de cultivares de cana-deaçúcar a herbicidas aplicados em pós-emergência. Bragantia. 68:941-951.

Tu M, Hurd C, Randall JM (2016) Weed Control Methods Handbook: Tools and Techniques for Use in Natural Areas. The Nature Conservancy, Wildland Invasive Species Team. 219p.

Zaccaro MLM, Byrd Jr JD, Russell D (2017) Tolerance of Several Legumes to Residual Imazapyr Applied Under Greenhouse Conditions. Weed Technol. 32(1):66-71. 